\title{
Isolation and characterization of insoluble inorganic phosphate solubilizer rice rhizosphere strain Enterobacter cloacae BAU3
}

\author{
Mahendra Singh \\ Department of Soil Science and Agricultural Chemistry, Bihar Agricultural University, \\ Sabour, Bhagalpur-813210 (Bihar), India \\ E-mail: m.singh30648@gmil.com
}

\section{Article Info}

DOI:10.31018/jans.v10i4.1929 Received: October 18, 2018 Revised: November 12, 2018 Accepted: November 17, 2018

\begin{abstract}
The objective of the present study was to isolate and characterize most efficient phosphate solubilizing bacteria (PSB) from rice rhizosphere. The study was carried out during the Kharif season'2018 at Department of Soil Science and Agricultural Chemistry, Bihar Agricultural University, Sabour, Bhagalpur, Bihar. The availability of phosphorous to plants for uptake and utilization is limited in soil due to fixation in the form of Fe-P, Al-P and Ca-P. The use of phosphate solubilizing bacteria can prove to be helpful measure to supply phosphorous to the crops to increase the productivity. In the present investigation, a total of 10 isolates were obtained from rice rhizosphere soil samples. All ten isolated isolates were shown phosphorus solubilization. Out of ten isolates BAU3 was found to be most potent phosphate solubilizers showing clear halo zone around its colony. The isolate BAU3 showed $20.00 \mathrm{~mm}$ phosphate solubilizing halo zone around its colony. The solubilization index $(\mathrm{SI})$ of the isolate BAU3 was also calculated at the end of the incubation period and observed phosphate solubilization index $(\mathrm{SI})$ of 3.22. The isolate BAU3 showed maximum insoluble phosphate solubilization of $450.24 \mathrm{mg} \mathrm{ml}^{-1}$ and isolates BAU3 was selected for subsequent studies. The bacterial isolates BAU3 was gram negative, non-spore forming rods shaped. On the basis of the 16SrDNA sequencing, isolate BAU3 was identified as Enterobacter cloacae strain BAU3 (Genebank Accession No. MK033472). The isolated strain of bacterial has potential to solubilize insoluble phosphorus and it can be utilized for preparation of microbial inoculants or biofertilizers.
\end{abstract}

Keywords: E. cloacae BAU3, Phosphate solubilizing bacteria, Rice, Solubilization index

\section{INTRODUCTION}

Phosphorus is one of the most important macro nutrient required by plants. It is a key nutrient for morphological, physiological and biochemical development of the plants. Also, it contributes to photosynthesis, energy and sugar production and nucleic acid synthesis (Saber et al., 2005). Plants absorb inorganic form of phosphorus $(P)$ which is essential element for plant growth and development making up to $0.2 \%$ of total plant dry weight. The level of available or inorganic phosphorus is very low in the soil and available $P$ is insoluble form. Aprpximately 50 percent of the total phosphorus in legume seeds and 60 to 70 percent in cereal grains is stored as phytin (Braum, et al, 1995). Movement of nutrients within the plant depends largely upon transport through cell membranes, which requires energy in the form of ATP and other $P$ compounds to oppose the forces of osmosis (Leandro et al., 2011). Phosphorus is taken up mostly as the primary orthophosphate ion $\left(\mathrm{H}_{2} \mathrm{PO}_{4}{ }^{-}\right)$, but some is also absorbed as secondary orthophosphate $\left(\mathrm{HPO}_{4}=\right)$. Phosphorus may be stored in the root or transported to the upper portions of the plants. Plants obtain phosphorous from soil solution as phosphate anions which are extremely reactive and get immobilized through precipitation with cations viz., $\mathrm{Ca}^{2+}, \mathrm{Mg}^{2+}$, $\mathrm{Fe}^{3+}$ and $\mathrm{Al}^{3+}$, depending on the soil $\mathrm{pH}$ (Kundu et al, 2009).

Plants acquire phosphorous from soil solution as phosphate anions which are extremely reactive and get immobilized through precipitation with cations such as $\mathrm{Ca} 2+, \mathrm{Mg} 2+, \mathrm{Fe} 3+$ and $\mathrm{Al} 3+$, depending on the particular properties of the soil. Several soil microorganisms known as phosphate solubilizing bacteria (PSB) have the ability to solubilizing insoluble mineral phosphate by producing various organic acids, siderophores, mineral acids, protons, humic substances, $\mathrm{CO} 2$ and $\mathrm{H} 2 \mathrm{~S}$. This results in acidification of the surrounding soil, releasing soluble orthophosphate ions $\left(\mathrm{H}_{2} \mathrm{PO}_{4}^{-}, \mathrm{HPO}_{4}{ }^{2-}\right.$ and $\left.\mathrm{PO}_{4}{ }^{3-}\right)$ which can be readily taken up by plants (Kundu et al, 2009).

Almost 75 to $90 \%$ of added $P$ fertilizer in agricultural soils is precipitated by iron, aluminum and calcium complexes present in soils. Furthermore, 
phosphatic fertilizers are expensive, and excessive use of rock phosphate (RP) is potentially and environmentally undesirable (Panhwar et al, 2011). To overcome phosphorus deficiency problems in soils by safe ways, low costs and eco friendly environment strategies, Phosphorus Solubilizing Bacteria (PSBs) have been used to solubilize the precipitated phosphates through converting them into soluble forms, $\mathrm{H}_{2} \mathrm{PO}_{4}{ }^{-}$and $\mathrm{HPO}_{4}{ }^{2-}$ that are available to plant (Coutinho et al., 2012). This occurs through principal mechanisms such as acidification of the medium, chelation, ion -exchange reactions and production of various low molecular weight organic acids (Chung et al., 2005 and Gulati et al., 2010). The majority of powerful PSBs that belong to bacteria as Pseudomonas, Enterobacter and Bacillus (Yadav et al., 2010 and Xiao et al., 2011). Rhizobium leguminosarum bv. Viciae have been demonstrated to solubilize inorganic phosphorus by Belal et al. (2013). The present study was designed to isolate, characterize and evaluation the phosphorous solubilization capacity of phosphate solubilizing bacteria.

\section{MATERIALS AND METHODS}

The present study was undertaken to isolate and characterize most efficient phosphate solubilizing bacteria from rice rhizosphere at Bihar Agricultural University, Sabour, Bhagalpur, India.

Soil sample collection: Soil samples were collected during kharif season of 2018 from rhizosphere of healthy rice plants from Research Farm of Bihar Agricultural University, Sabour (longitude 87o2'42"East and latitude 25015'40" North at altitude of 46 meters above mean sea level in the heart of the vast Indo-Gangetic plains of North India.) Bhagalpur, India, stored in polyethylene bags and brought to the laboratory for further studies. The collected soil samples were silty clay loam having $\mathrm{pH} 7.1$, Electrical conductivity 0.24 , $\mathrm{dSm}^{-1}$, organic carbon 0.53 per cent, available phosphorus $11.98 \mathrm{~kg} \mathrm{ha}^{-1}$, available potassium $195.00 \mathrm{~kg} \mathrm{ha}^{-1}$ and nitrogen $185.00 \mathrm{~kg} \mathrm{ha}^{-1}$.

Isolation of phosphate solubilizing bacteria (PSB): Phosphate solubilizing bacterial (PSB) isolates were obtained by dilution plating method, the air-dried ten grams soil from each soil sample was suspended in a $90 \mathrm{ml}$ of sterilized water blank and successively diluted up to seven time dilution, than one $\mathrm{ml}$ suspension were transferred to the sterilized petri plate. Transfer $15 \mathrm{ml}$ of sterilized Pikovskaya's agar medium (PKV) to the plate (Pikovskaya 1948) (The composition is as follows $\left(\mathrm{g} \mathrm{l}^{-1}\right)$ : Glucose, $10 \mathrm{~g}$; tricalcium phosphate (TCP), $5 \mathrm{~g}$; ammonium sulphate, $0.5 \mathrm{~g}$; sodium chloride, $0.2 \mathrm{~g}$; potassium chloride, $0.2 \mathrm{~g}$; magnesium sulphate, $0.1 \mathrm{~g}$; yeast extract, $0.5 \mathrm{~g}$; manganese sulphate, trace; ferrous sulphate, trace; agar, $15 \mathrm{~g}$; the $\mathrm{pH}$ was adjusted to $7.0 \pm 0.2$ ). Pure culture of the isolates were made by repeated sub culturing on fresh PKV plates and maintained on PKV slants at the refrigerated condition. The one $\mathrm{ml}$ suspensions of desired dilutions were plated on Pikovskaya's agar medium and plates were incubated at $28 \pm 2^{\circ} \mathrm{C}$ for $3-5$ days. The bacterial colonies surrounded with a halo zone were purified by streaking method then maintained on Pikovskaya's Agar slants at $4{ }^{\circ} \mathrm{C}$.

Screening of isolates for phosphate solubilization Primary screening: All the halo zone bearing colonies were screened for phosphate solubilization on PKV medium in petriplates. The isolates showing phosphate-solubilizing ability were inoculated on the PKV plate and incubated at $28 \pm 2^{\circ} \mathrm{C}$ for 3-7 days. The diameter of colony and solubilization zone was measured. Phosphate solubilization index $(\mathrm{SI})$ was calculated by measuring the colony diameter and the halo zone diameter and the colony diameter, using the following formula of Premono et al., 1996.

Phosphate Solubilization Index $(\mathrm{SI})=($ Colony diameter + Halo zone diameter) $\times /$ Colony diameter ..Eq.1 $50 \mathrm{ml}$ of Pikovskaya's broth medium with tricalcium phosphate was prepared and sterilized then inoculated with the specific amount $(5-10 \%$ of the broth) of the isolate. Then the inoculated sample was incubated for 48 hours on rotatory shaker at $150 \mathrm{rpm}$ at $28 \pm 2^{\circ} \mathrm{C}$ for $3-7$ days, after incubation culture broth was centrifuged at $10,000 \mathrm{rpm}$ for $5 \mathrm{~min}$ and the supernatant was used to estimate the $P$ release. The $P$ was measured spectrophotometrically (Systronic UV-VIS Spectrophotometer 117 ) at $430 \mathrm{~nm}$ according to Subba (1993).

Characterization of bacterial isolates: All bacterial isolates were screened on the basis of formation of clear halo zone around the colonies. The highest phosphorus solubilizing activity of isolate (wider halo zone having more diameter and thickness) were selected for morphological, biochemical tests Bergey's Manual of Systemic Bacteriology (Buchanan, 1974).

$16 S$ rRNA gene sequencing and analysis: Molecular characterization (included DNA extraction and polymerase chain reaction (PCR) and $16 \mathrm{~S}$ rDNA gene sequencing technique was conducted using $\mathrm{ABI} 3730 \mathrm{xl}$ DNA sequencer at at Xcelris Labs Ltd. Gujrat, India). To determine the phylogenetic relationship, the $16 \mathrm{~S}$ rRNA gene- sequence of isolated and screened bacterial strain was obtained using the 16S rRNA gene -specific universal primers: 8F and 1492R. The 16S rRNA gene sequence of the isolated strain was analyzed at NCBI GenBank (http:// www.ncbi.nlm.nih.gov) using BLAST (N) program (Zhang et al, 2000). Phylogenetic tree was constructed by neighbor joining method for this alignment using the MEGA 6 (Molecular Evolutionary Genetics Analysis) software (Tamura et al, 2013 
$a, b)$. The final sequence was submitted at GenBank (Thompson, et al, 1997).

Statistical analysis: All experiments were performed in triplicate, and the results were expressed as the mean.

\section{RESULTS AND DISCUSSION}

Isolation and screening of phosphate solubilizing bacteria: Rice rhizosphere soil samples were collected from five rice crops of Bihar Agricultural University Research farm, Sabour, Bhagalpur, Bihar and a total of 10 morphologically distinct colonies isolates were isolated (Table 1). The colony of isolate BAU3 was observed gram negative, round in shaped, white in colour and having entire edge. Similar results were obtained by Borham et al., 2017, who isolated the most efficient phosphate solubilizing bacterial strain isolated from rhizosphere of healthy rice plants and identified as Enterobacter cloacae (B1) based on morphological and biochemical characteristics and $16 \mathrm{~S} r$ DNA. Till today numerous works have been done by different researchers, like Vazquez et al. (2000) who isolated many isolate of PSBs from mangrove soil and reported that out of all isolates $\mathrm{V}$. proteolyticus was found to be most active. Similarly, Kannapiran et al. (2011), isolated Pseudomonas, Bacillus, Vibrio, Micrococcus, Flavobacterium, Corynebacterium, Alcaligenes and Enterobacter from samples collected from different stations of the Thondi coast.

Inorganic phosphorus solubilization efficiency: In the present investigation, the phosphate solubilizing efficiency (Qualitative) of isolates was determined by the plate assay where 10 isolates were spotted on Pikovskaya's agar medium plate as per

Table 1. Colony characteristics of phosphate solubilizing bacterial isolates isolated from rice rhizospheric soil.

\begin{tabular}{llllllll}
\hline Isolate & Shape & Edge & Opacity & Colour & Elevation & Texture & $\begin{array}{l}\text { Gram } \\
\text { staining }\end{array}$ \\
\hline BAU1 & Irregular & Undulate & Opaque & White & Raised & Mucoid & Negative \\
BAU2 & Round & Undulate & Opaque & White & Raised & Mucoid & Negative \\
BAU3 & Round & Entire & Opaque & White & Raised & Mucoid & Negative \\
BAU4 & Round & Undulate & Opaque & White & Flat & Mucoid & Negative \\
BAU5 & Irregular & Undulate & Translucent & White & Raised & Mucoid & Negative \\
BAU6 & Irregula & Undulate & Opaque & White & Raised & Mucoid & Negative \\
BAU7 & Round & Undulate & Opaque & White & Raised & Mucoid & Negative \\
BAU8 & Irregular & Undulate & Opaque & White & Flat & Mucoid & Negative \\
BAU9 & Round & Entire & Opaque & White & Raised & Mucoid & Negative \\
BAU10 & Round & Undulate & Opaque & White & Raised & Mucoid & Negative \\
\hline
\end{tabular}

Table 2. Phosphate solubilization by PSB isolates isolated from rice rhizosphere.

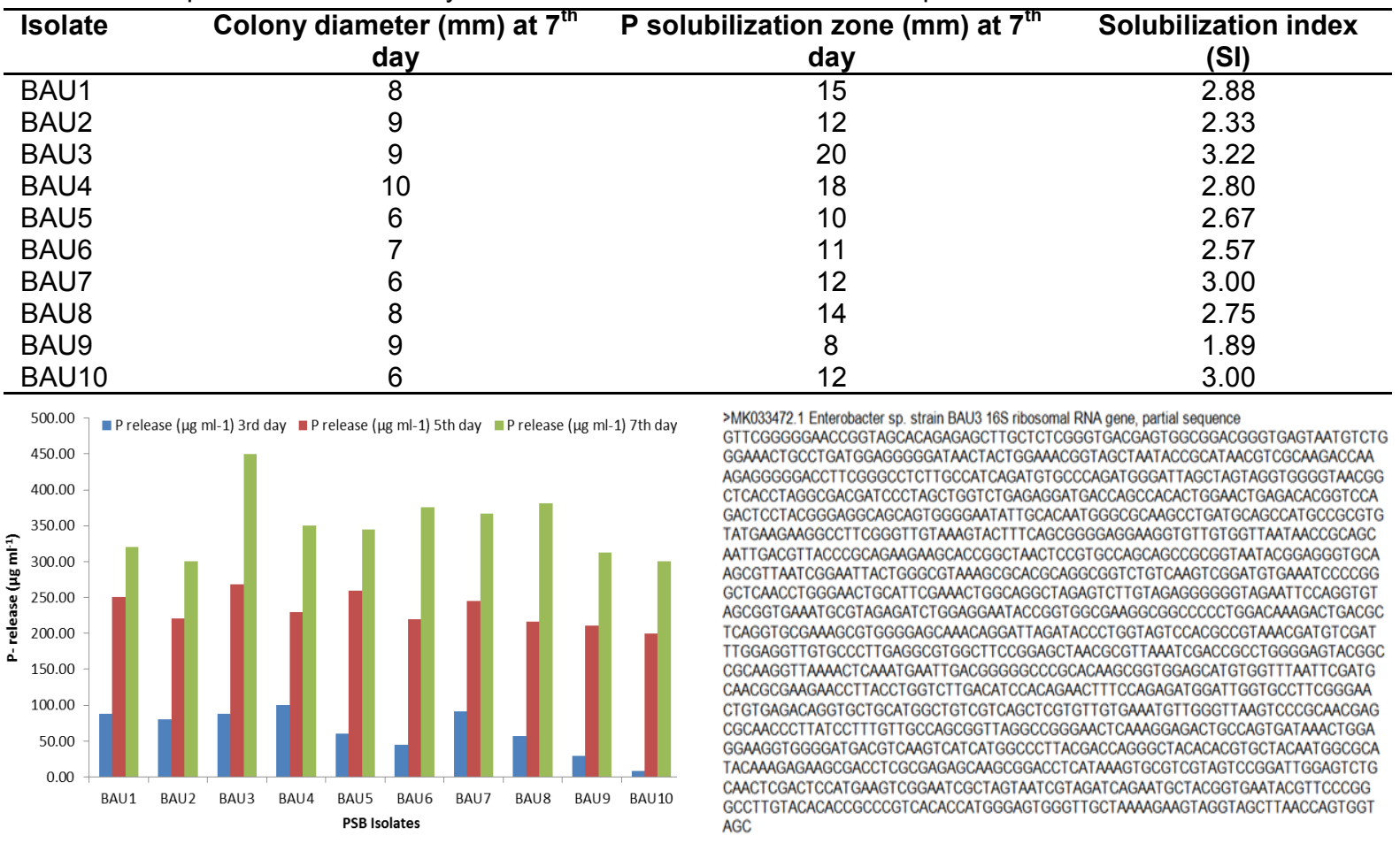

Fig. 1. $P$-release $\left(\mu \mathrm{g} \mathrm{ml}^{-1}\right)$ by $P S B$ isolates isolated from rice rhizosphere.

Fig. 2. FASTA sequences of the PSB (E. cloacae strain $B A \cup 3)$. 


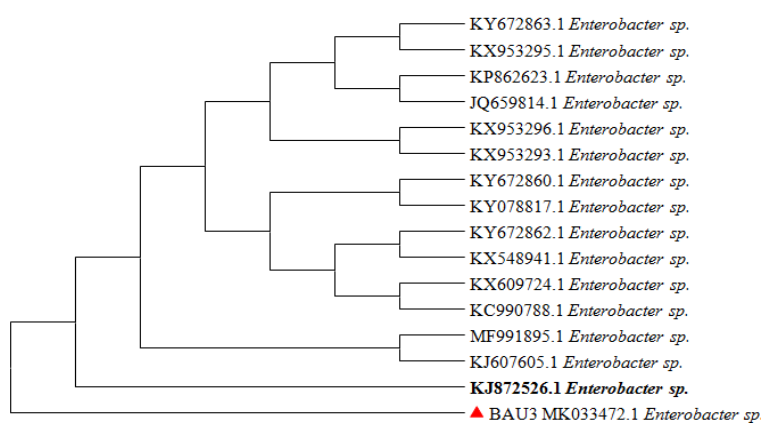

Fig.3. Phylogenetic tree: Amplified 16S rRNA gene fragment from the isolated strain Enterobacter cloacae BAU3 was sequenced and blast searched though NCBI database. Closely related sequences were downloaded and aligned using CLUSTAL W. These sequences were analyzed using maximum likelihood (ML) method. The bootstrap replicates (BS) values of $70 \%$ or greater represent well supported nodes and thus only those were retained. Enterobacter cloacae AJ1 with accession number KJ872526.1 taken as out group. Enterobacter strain BAU3 present in the group containing Enterobacter cloacae strains.

the primary screening technique described by Kundu et al. (2009). On the basis of the halo zone and isolate diameter Solubilization Index (SI) was calculated (Kannapiran et al., 2011). The PSB isolate BAU3 was found to be most potent phosphate solubilizer showing clear halo zone around its colony. The PSB isolate BAU3 showed 20.00 $\mathrm{mm}$ phosphate solubilizing halo zone around its colony (Table 2). The solubilization index (SI) of the isolated strain BAU3 was also calculated at the after ten days of incubation period and observed phosphate solubilization index (SI) of 3.22. The halo zone formation around the bacterial colonies could be due to the production of low molecular weight organic acids viz., succinic acid, palmatic acid, gulutamic acid, oxalic acid or due to the production of polysaccharides or due to the activity of phosphatase enzymes of phosphate solubilizing bacterial strains (Paul and Sinha, 2013). The obtained results were conformity with the Kumar et al. (2012) who observed the halo zone of solubilization up to $20 \mathrm{~mm}$ on Pikovskaya agar plates by Enterobacter sp. Pseudomonas sp. was the most efficient phosphate solubilizers on Pikovskaya's agar plates it gaven solubilization index $228 \pm 6.12$ at 7 th day incubation which were shown by Kannapiran et al. (2011).

The phosphate solubilizing efficiency of all ten isolates Pikovskaya's broth indicated that the all isolates efficiently solubilized inorganic phosphate in the medium containing $0.5 \%$ tri-calcium phosphate (Fig 1). PSB isolate BAU3 was produced $450.24 \mathrm{~g} \mathrm{P} \mathrm{ml}^{-1}$ in soluble phosphate in the PKV broth after the $7^{\text {th }}$ day of the incubation period. It might be due to the more secretion of low molecular weight organic acids, secrete phosphatases enzymes which increase the solubilization of insoluble phosphate. The similar results were obtained by Banerjee et al., 2010, who reported that maximum phosphate solubilization efficiency of the isolated Bacillus sp. was after incubation of $96 \mathrm{~h}$. The results are also in agreement with the results of Thakur and Putatunda (2017), who isolated the isolate IH37 (Enterobacter aerogenes) and the isolate IKas4 (Enterobacter sp.) which were showed maximum phosphate solubilization of $0.070 \mu \mathrm{g}$ and $0.99 \mu \mathrm{g} \mathrm{P} \mathrm{ml} \mathrm{P}^{-1}$ respectively. Both bacterial isolates were gram negative, non-spore forming rods. On the basis of the 16SrDNA sequencing isolates IKas4 and IH37 were identified as Enterobacter aerogenes and Enterobacter sp. Respectively.

The results are also conformity with the findings of Kundu et al. (2009) who demonstrated that the Psolubilization in PVK broth, the maximum number of bacteria showed P-solubilization $<50 \mu \mathrm{g} \mathrm{P} / \mathrm{ml}$. As we compare the results of solubilization index and quantitative $P$ solubilization we find that all the 10 isolates showed phosphorus solubilization. Out of the 10 isolates, highest phosphate solubilizing efficiency was shown by BAU3 and on its basis isolates showing maximum solubilization index and phosphate solubilization were selected for subsequent studies.

Characterization of selected Enterobacter cloacae strain BAU3: To identify the selected isolated bacteria isolate BAU3, 16S rRNA sequencing was performed. BLAST search analysis was carried out for the 16S rRNA sequences thus obtained using NCBI-Gene Bank database that showed a sequence identity of $99.0 \%$ with Enterobacter cloacae strain AJ1 (GeneBank accession number KJ872526.1). The FASTA sequence was submitted to GenBank with the accession number MK034472 (Fig. 2). Since the BLAST analysis revealed the alignment of the $16 \mathrm{~S}$ rRNA sequence with a number of species of the genus Enterobacter, we used the most similar sequences to construct a phylogenetic tree using neighbour joining method (Fig. 3). Based on maximum identity score first fifteen sequences were selected and aligned using multiple alignment software program CLUSTAL W (Thompson et al., 1997). These sequences were analyzed using maximum likelihood (ML) method as outlined by Mirza et al., (2009). It was evident from the phylogenetic tree that the isolated organism E. cloacae was assigned as E. cloacae MK033472. Similarly, Ahemad and Khan (2010) was isolated Enterobacter asburiae strain PS2 from the mustard rhizosphere and was assessed for the fungicide-tolerance and production of plant growth promoting traits (phosphate solubilization, siderophores, indole acetic acid, exopolysaccharides, hydrogen cyanide and ammonia production) both in the presence and absence of fungicides. 
Nucleotide sequence accession numbers: The 16S rDNA sequences were carry out by BLAST alignment search tool at the National Centre for Biotechnology Information web site (www.ncbi.nlm.nhi.gov), and submitted to GenBank. Based on maximum identity score first Fifteen sequences were selected and aligned using multiple alignment software program ClustalW with accession number; stored in the NCBI database E. cloacae strain AJ1 (GeneBank accession number KJ872526). The NCBI has issued the nucleotide accession number MK033472 to Enterobacter cloacae strain BAU3. The similar organism E. cloacae strain BAB-6019 (GeneBank Accession Number KY672863) was isolated (Nagar et al., 2017).

\section{Conclusion}

A total of 10 isolates were obtained from five rice rhizosphere soil samples. Out of ten isolates, BAU3 was found most potent insoluble phosphate solubilizer. BAU3 was identified as Enterobacter cloacae (Genebank Accession Number MK033472) by 16s rDNA sequencing. The isolated bacterial strain seemed to be highly potent to solubilize insoluble phosphate. The biological nitrogen fixation efficiency of this strain may be explored and can be utilized for preparation of biofertilizers.

\section{ACKNOWLEDGEMENTS}

This work is a part of an ongoing research project "Development of Liquid Microbial Inoculants (Biofertilizers) formulations" which is financially supported by the Bihar Agricultural University, Sabour, Bihar, India. Authors also thankful to Dr. Jitendra Saini, Assistant Professor, Department of Microbiology, Central University, Mahendra Garh, Haryana, India, who guided for molecular characterization of bacteria.

\section{REFERENCES}

1. Ahemad, M. and Khan, M.S. (2010). Plant growth promoting activities of phosphate-solubilizing Enterobacter asburiae as influenced by fungicides, Eur. Asia J. Bio. Sci., 4: 88-95

2. Banerjee S., Palit, R., Sengupta C. and Standing, D. (2010). Stress-induced phosphate solubilization by Arthrobacter sp. and Bacillus sp. isolated from tomato rhizosphere, Aust. J. Crop Sci,. 4: 378-383.

3. Belal, E.B., Hassan, M.M. and El-Ramady, H.R. (2013) Phylogenetic and characterization of salttolerant rhizobial strain nodulatingfaba bean plants. Afr. J. Biotechnol, 12 (27), 4324-4337.

4. Borham, A., Blal, M., Metwaly and Gremy, S. El. (2017). Phosphate Solubilization by Enterobacter cloacae and its Impact on Growth and Yield of Wheat Plants, J. Sus. Agric .Sci. 43(2): 89 -103.

5. Braum, S. M. and Helmke, P. A. (1995). White lupin utilizes soil phosphorus that is unavailable to soybean. Plant Soil, 176:95-100.

6. Buchanan, R.E. and Gibbons, N. E. (1974): Bergey's
Manual of Determinative Bactriology, 8th ed. Baltimore: Williams \& Wilkins Co.

7. Chung, H., Park, M., Madhaiyan, M., Seshadri, S., Song, J., Cho, H. and Sa, T. (2005) Isolation and characterization of phosphate solubilizing bacteria from the rhizosphere of crop plants of Korea. Soil Biol. Biochem., 37, 1970-1974.

8. Coutinho, F.P., Felix, W.P. and Yano-Melo, A.M. (2012) Solubilization of phosphates in vitro by Aspergillus spp. and Penicillium spp. Ecol. Eng. 42, 85-89.

9. Gulati A, Sharma N, Vyas P, Sood S, Rahi P, Pathania V. and Prasad, R. (2010) Organic acid production and plant growth promotion as a function of phosphate solubilization by Acinetobacter rhizosphaerae strain BIHB 723 isolated from the cold deserts of the trans-Himalayas. Arch Microbiol, 192:975-983

10.Kannapiran, E. and Ramkumar, V. (2011). Isolation of phosphate solubilizing bacteria from the sediments of Thondi coast, Palk Strait, Southeast coast of India. Annals Bio. Res. 2: 157-163.

11.Kumar, T., Kumar, V. and Anshumali. (2012). Phosphate Solubilizing Activity of Some Bacterial Strains Isolated from Chemical Pesticide Exposed Agriculture Soil. Inter. J. Engg. Res. Dev; 3: 01-06.

12.Kundu, B. S., Nehra, K., Yadav, R. and Tomar, M. (2009). Biodiversity of phosphate solubilizing bacteria in rhizosphere of chickpea, mustard and wheat grown in different regions of Haryana. Ind. J. Microbiol; 49:120-127.

13.Leandro, M. M., Oliveira, S. M., Soares, C. R. F. S. and Moreira, F. M. S. (2011). Solubilisation of Inorganic Phosphates by Inoculant Strains From Tropical Legumes. J. Agric. Sciences., 68:603-609.

14. Mirza B S, Welsh A, Rasul G, Rieder, J.P., Paschke M.W. and Hahn, D. (2009) Variation in Frankia populations of the Elaeagnus host infection group in nodules of six host plant species after inoculation with soil. Microbial Ecol. 58:384-393

15.Nagar, N.R., Amaresan, N., Patel, A. and Bhargava, P. (2017). Gujarat Biodiversity Gene Bank, Gujarat State Biotechnology Mission, 9th floor, 11th Block, Udyogbhavan, Gandhinagar, Gujarat 382010, India

16.Panhwar, Q.A., Radziah, O., Zaharah, A.R., Sariah, M. and Razi, I.M. (2011) Role of phosphate solubilizing bacteria on rock phosphate solubility and growth of aerobic rice. J. Environ. Biol., 32, 607-612.

17.Paul, D. and Sinha, S.N. (2013). Isolation of phosphate solubilizing bacteria and total heterotrophic bacteria from river water and study of phosphatase activity of phosphate solubilizing bacteria, Adv. Appl. Sci. Res. 4: 409-412.

18.Pikovskaya, R.I. (1948). Mobilization of phosphorus in soil in connection with vital activity of some microbial species. Microbiologiya, 17: 362-370

19.Premono, M. E., Moawad A.M., P Vleck.L.G. (1996). Effect of phosphate solubilizing Pseudomonas putida on the growth of maize and its survival in the rhizosphere, Indones. J. Crop Sci. 11: 13-23.

20.Saber, K., Nahla, L.D. and Chedly, A. (2005) Effect of $\mathrm{P}$ on nodule formation and $\mathrm{N}$ fixation in bean. Agron Sustain Develop., 25, 389-393. doi: 10.1051/ agro:2005034

21.Subba, R.N.S. (1993). Biofertilizeres in Agriculture and Forestry, 3rd ed., Oxford and IBH Publishing Co. Pvt. LTD., New Delhi. pp.129-135.

22.Tamura K., Peterson D., Peterson N., Stecher G., 
Nei M., and Kumar S. (2013a). MEGA5: Molecular Evolutionary Genetics Analysis using Maximum Likelihood, Evolutionary Distance, and Maximum Parsimony Methods. Molecular Biology and Evolution 28: 2731-2739.

23.Tamura K., Stecher G., Peterson D., Filipski A. and Kumar S. (2013b). MEGA6: molecular evolutionary genetics analysis version 6.0, Mol. Biol. Evol. 30: 2725-2729.

24.Thakur, I.B. and Putatunda, C. (2017). In vitro Phosphate Solubilization by Enterobacter spp. Isolated from Wheat Rhizosphere, J Pure and Applied Microbiology; 11(4): 2007-2015.

25.Thompson, J.D., Gibson, T.J., Plewniak, F., Jeanmougin, F. and Higgins, D.G. (1997). The CLUSTAL_X windows interface: flexible strategies for multiple sequence alignment aided by quality analysis tools. Nucleic Acids Res. 25:4876-4882

26.Vazquez, P., Holguin, G., Puente, M. E., Lopez, C. A., Bashan, J. (2000). Phosphate-solubilizing microorganisms associated with the rhizosphere of mangroves in a semiarid coastal lagoon. Bio. Fert. Soils. 30: 460-468.

27.Xiao, C.Q., Chi, R.A., Li, X.H., Xia, M. and Xia, Z.W. (2011). Biosolubilization of rock phosphate by three stress-tolerant fungal strains. Appl. Biochem. Biotechnol., 165, 719-727.

28.Yadav, J., Verma, J.P., Yadav, S.K. and Tiwari, K.N. (2010). Effect of salt concentration and $\mathrm{pH}$ on soil inhabiting fungus Penicillium citrinum Thom for solubilization of Tricalcium phosphate. Microbial. J. 1:1-7

29.Zhang Z., Schwartz S., Wagner L. and Mille, W. (2000). A greedy algorithm for aligning DNA sequences, J. Comput. Biol. 7: 203-214. 